\title{
Population, ethics, and equity
}

\author{
População, ética e eqüidade
}

Giovanni Berlinguer 1

1 Scuola di Bioetica
Università degli Studi
di Roma "La Sapienza".
Piazzale Aldo Moro 5,
00185, Roma.
berlinguer@axrma.uniroma1.it
Abstract Demography is impregnated, more or less explicitly, with ethical contents. This is apparent in the words used to support data, which change over time (e.g., the term "ill egitimate child" is no longer used). Ethical princi ples must be analyzed because demography concerns both public policies and individual choice. There is a conflict in this area between the idea of the ethical state, dictating personal behaviors to citizens, and that of decisions based on freedom, supported by three shared values: human rights, pluralism, and equity. This paper examines how these could be reinterpreted in the context of choices regarding population.

Key words Demography; Public Policy; Bioethics; Legislation

Resumo A demografia está impregnada, mais ou menos explicitamente, de conteúdos éticos. Isto é aparente nos termos usados para sustentar dados, que mudam ao longo do tempo (por exempl o: a expressão "criança il legítima" não é mai s usada). Os princípi os éticos precisam ser analisados, porque a demografia diz respeito a tanto políticas públicas, quanto escolha individual. Nessa área há um conflito entre a idéia do estado ético determinando comportamentos pessoais aos ci dadãos e a idéia de que as deci sões devem ser baseadas na liberdade, sustentada por três val ores compartilhados: di reitos humanos, plurali smo e eqüi dade. $O$ artigo examina como esses val ores podem ser reinterpretados no contexto das escol has que dizem respei to à população. Palavras-chave Demografia; Política Social; Bioética; Legislação 
Words and values in democracy

Population dynamics (and the individual and collective decisions that support them) are increasingly becoming the object of statistical analysis and moral considerations. As a result, we observe the emergence of new controversies and the need for more in-depth studies. On the one hand, these involve the correct definition of a government based on principles of equity and respect for fundamental ethical norms and faced with difficult tasks in the area of demographic problems. Policies related to migration and inter-generational and intergender relations, to mention only a few, have manifested themselves clearly in recent years. On the other hand, they concern individual choices, where principles of autonomy and responsibility appear to intertwine. This occurs especially in phases of human life that are increasingly affected by advances in the biomedical sciences: genetics, procreation (natural or artificial), healing, and terminal stages of life.

Several difficulties arose as I attempted to wend my way through all the ethical issues related to these matters. The first was the wide range of problems already made apparent by the above-mentioned example. In order to draw a more precise picture, I used the new edition of the Encyclopedia of Bi oethics organized by W.T. Reich (1995). The entry on 'population ethics' includes the following secondary topics: normative approaches, religious traditions, population policies, fertility control strategies, migration, and refugees. Related topics that should be added can be found in other parts of the collection: death and dying, eugenics, aging and the aged, euthanasia and sustaining life, freedom and coercion, epidemics, sexuality, children, future generations (obligations to), reproductive technologies, food policy, race and racism, women, international health, environmental policy and law, abortion, genetics and environment in human health, and marriage and other domestic partnerships.

I felt unsure as to how I should interpret this long and still incomplete list: as a sign of the pervasive nature of population-related issues or of the invasive trend of bioethics? Bioethics is perceived in a variety of ways by experts, but they all agree that it is the most recent and promising branch of moral philosophy. Some see it in a narrower sense, as if pertaining only to ethical problems related to recent advances in biomedical sciences. Others see it in a more comprehensive way, contending that ethics has always focused on life's problems in general. I personally believe that the first definition neglects not only the historicity of behaviors and ideas regarding the relationship between ethics and life (birth, growth, nature, disease, and death), but also the cross-cutting nature of daily experience (for example, what is the relationship between strictly scientific experiments, i.e., the fact that individual therapy is somehow experimental, and the dissemination of new drugs, which at times constitutes a real experiment with humans and other living creatures?). I al so think that ethics encompasses moral antitheses (e.g., love/ hate, tolerance/ intolerance, virtue/ vice), which should be included in the biological sphere. Considering that 'too much is as bad as too little' and that 'walking the middle road leads to perfection' (Confucius), I prefer a comprehensive (albeit not generalizing) definition of bioethics as the whole of life problems in their material aspects. This would allow us to link cutting-edge bioethics (concerned with emerging issues, e.g., medically assisted procreation and genetic engineering) to daily bioethics, based on moral choices which, made in the context of shared experiences, regard both individuals and populations.

My second difficulty appeared in the analysis of the language of demography. As I proceeded, I realized that this science (as many others) has countless words impregnated not only with descriptive meaning, but also with values or pseudo-values, that is, with moral attributes which change over time and according to the culture or the individuals who introduce and use them. The word 'illegitimate', for example, defining children of unmarried parents, was used for many years as both a statistical category and a stigma. This changed when the new Diritto di Famiglia (Act 1064 of October 31, 1955), established that all public acts and documents should refer only to general facts about individuals and not those of their parents. Even statistics had to adjust to this rule. Another word, stirpe (an Italian term for individuals and peoples of high lineage or superior descent) had al ready become obsolete, yet remained in TitleX of the Criminal Code adopted in 1930 (named Rocco Code, by the surname of facist Minister of Justice, Royal decree of October 19, 1930, no 1398). It provided that abortion, the induced inability to procreate, encouragement for practices against procreation, and infection by syphilis and gonorrhea were all considered crimes against the integrity and health of the stirpe. These were considered offenses because they were contrary to the state's demographic interest. Homosexuality, a neutral word per se, was long associated with the 
notion of guilt (as it still is in the criminal codes of some countries) and considered a pathological entity on the same level with other diseases, until scientific advances and civil rights movements eliminated this connection, at least in disease statistics. But stigmata come and go. Another word is now becoming increasingly common in both daily language and statistical surveys (although to a lesser extent): 'community outcasts', i.e. marginal people, outside the mainstream, defined according to the criterion of social exclusion, even by many of those who advocate inclusion.

In other cases we could speak of omitted words. One of these is the word 'starvation', ignored by mortality statistics, even though it is one of the most important direct causes of death and a major indirect cause of associated diseases and immunodeficiencies. Although it is omitted today, it appeared in one of the first modern works on the study of populations. In Natural and Political Observations Upon the Bills of Mortality (presented by John Graunt to the Royal Society in 1662) six people were described as dead of starvation on the streets of London in 1632 (Fagot-Largeault, 1989:87). The word 'poverty' was not used until 1955, by World Health Organization Director-General Nakajima (after a long silence by the WHO on the matter). While presenting to the press the official report on The State of World Health (WHO, 1995), he pointed out that the main cause of death in the world was poverty, yet the word itself has never appeared in mortality statistics classified by cause of death. One could argue that the direct clinical cause of death is always something else, never poverty itself, but this could also indicate medicine's tendency (more than that of demographic sciences) to 'medicalize' every aspect of human life, using aseptic terms which disguise differences and conflicts in social relations. This could also explain why this century's epidemiological transition is commonly recognised as the passage from the prevalence of infectious diseases to that of chronic-degenerative (or, more accurately, non-infectious) diseases. This definition neglects or hides another significant difference. In the past, physiogenic diseases prevailed, due mainly to natural factors (infection, climate, deprivation) and men were passive objects or secondary agents with respect to disease factors from the external environment. Now, on the contrary, most diseases are predominantly anthropogenic, i.e., caused mainly (though not exclusively) by changes in the environment and interpersonal relations, brought about by human activity or by the lack of corrective measures.
Finally, I could mention two definitions, routinely employed by statistics, where I have just begun to identify scientific limits and related ethical implications. The first is spontaneous abortion, used in opposition to induced abortion. If spontaneity, according to Leibnitz' classic definition, is contingentia sine coactione, abortion can only be considered spontaneous when caused by natural events, like maternal age and conditions (which might increase probability of the occurrence) or by selective features in the embryo that make it impossible to prevent risks. Very often, however, abortions induced unintentionally but as a predictable consequence of harmful actions are recorded as spontaneous. This would be the case of abortions caused by accidents, violence, environmental factors, working conditions, preventable diseases, or stress during pregnancy. Even genetic changes in the two gametes, which often give rise to an embryo destined to be aborted, are not always classified as spontaneous causes. They are frequently caused by harmful factors (radiation and toxic substances) affecting one of the parents in the workplace (Talamanca, 1994). Since the word spontaneity evokes (spontaneously) the ineluctability of a phenomenon, thus leading to resignation, the absolving, extensive, and inadequate use of the expression 'spontaneous abortion' leads to clear conceptual and practical omissions. By the way, still regarding abortion, I could add a short comment about another commonly used expression, also carrying a value judgment and often inappropriate: 'therapeutic abortion'. The only correct use for this definition is in those cases where the interruption of pregnancy was motivated by the need to treat ongoing diseases in the mother or to prevent risk to her life (situations made rare by advances in medicine). Instead, this expression is often employed to describe abortions caused by fetal anomalies found through increasingly common prenatal diagnostic techniques. In this case, it appears as a strange therapy, for it brings to an end the very vital process it intended to cure in the first place.

The other definition I have examined is the distinction between endogenous and exogenous mortality. I shall dwell at length upon this topic at another time (Reich, 1995:940-946), limiting myself, for the moment, to a few observations. Obviously, some deaths are due to (almost) exclusively endogenous causes (e.g., genetic) or to (almost) exclusively exogenous causes (e.g., violent). Over the past one hundred years, at two different times, we have seen that one type tended to prevail over the other. 
The late 19th century, with all its microbiological discoveries, was characterized by the idea that external enemies (microorganisms) were the cause of all disease. The late 20th century is apparently committed to finding one gene responsible for every nosologic condition (as much as for every behavior considered abnormal, here incorporating the worst of the positivist tradition). Without underestimating the cognitive and taxonomic values of these interpretations, one must recognize that the concepts of endogeny and exogeny have changed repeatedly due to cultural factors (scientific discoveries) and trends in the objective description of diseases (e.g., changes in knowledge and theories regarding the origin and evolution of tumors).

What must be considered is the fact that diseases are oftentimes the body's focal point in the relationship between internal and external environments, between individual predisposition and hazardous living and working conditions. Blaming only external factors, i.e., those in nature (microbes and others), or internal ones, those in man (genes), could both lead to an epistemological blindness towards the variety and complexity of morbigenic factors and hamper efforts to prevent the aggression of microbes and other external factors (which strike mainly the weakest subjects) or to keep vulnerability to disease from turning into morbid or lethal events (Reich, 1995:940-946). Both trends could hinder proposals for adequate government measures in health prevention, which, according to William Farr (1885), constitute one of the purposes of mortality statistics (Fagot-Largeault, 1989:89).

\section{The ethical basis of population policies}

I do not deny that the selection of examples, and my related comments, are also biased by experience and a specific evaluative perspective. Nevertheless, I am equally convinced of the validity of the critical exercise of reflection on these and other words (past and present) employed in demography, since it may unveil their moral significance.

The previous quote from Farr could serve as a guide for the following discussion. It begins with the notion that practical or moral philosophy (ethics) involves choosing what is right, selecting between good and bad (whereas theoretical philosophy - forgive me for the simplification - investigates being and truth, while aesthetic philosophy investigates beauty). We must therefore inquire as to the relationship between ethics and the government of public issues. This government includes or should include population policies, due to their intrinsic relevance and growing importance.

This is essential, even if in Italy and Europe in general more than fifty years after the fall of Fascism and Nazism there still is some hostility towards any sound demographic policy. It is believed that every action in this field results, almost inexorably, in the 'numbers = power' aberration or in racism followed by genocide. What is the current substitute for the necessary conscious choices?

Very often prejudice. The attitude towards immigration is a typical example. Of course immigration must be regulated, but the flow cannot be seen as an impending misfortune for Italians, eliminating jobs, bringing disease, and contaminating the stirpe (an Italian term to characterize individuals and peoples of superior lineage) in such a way that, with the maintenance of low fertility rates, the population of Italian origin would disappear completely in 150-200 years. I must add a personal statement here. Since I am originally from Sardinia, I nurse the hope that in some small village in the hills and mountains of the island, there might still be a specimen of Homo sardus who, according to studies by Cavalli-Sforza (1996), would represent, together with the Basques, the only population genetically different from the Mediterranean peoples. As we all know, all other populations have undergone a deep and fruitful process of hybridization. Concerning the other issues mentioned above, we all know that immigrants do not steal jobs, rather they occupy positions no longer appealing to Italians. Secondly, with a few exceptions, they do not bring diseases, but acquire them after they arrive in Italy. They are actually some of the healthiest citizens of their respective countries, otherwise they would not be fit for immigration (Berlinguer, 1996). Nevertheless, even in Italy 'the poison and violence of intolerance' emerge, even if limited by the fact that "in our country there is some historical memory (the importance of emi gration for us and its consequent sufferings), a widespread Catholic culture (advocating respect and aid for the poor and oppressed), and the attention of democratic forces denouncing and fighting such behaviors" (Golini, 1989).

When there is prejudice, population policies are replaced by rhetoric. The family (again, a topic linked to procreation) is a typical example. I believe there is no other country in Europe where the highest level of rhetoric in favor of families is so strikingly accompanied by a 
minimum level of practical support for couples and children. Without a doubt, public policies in Italy "have totally neglected the family and, to a certain extent, have penalized it with legislation on housing, work, taxes, and aid to dependent children" (Golini, 1994:10). It was not until 1996 (when financial more than ethical or social reasons produced updated documentation and promoted in-depth analysis on the reform of the welfare state) that we became fully aware of two basic premises: 1) that social expenditures in Italy are slightly lower than the average for the European Union and 2) that there is a huge imbalance between the funds invested in old-age and retirement pensions and those directed towards families and youngsters through aid to dependent children, vocational training, unemployment insurance, and other welfare benefits.

We are now beginning to reflect on the alltime record drop in fertility rates and number of births, with different interpretations for the cause-effect relations. The phenomenon is due to a lesser extent to the potential increase in biological sterility (although this is not negligible, for ethical and health-related reasons) and to a greater extent to social and cultural sterility, i.e., to the limited tendency to procreate. To avoid interfering with the principle of individual and family autonomy in procreative decisions (on the contrary, in order to ensure this right for everyone), the least society could do would be to "eliminate the burden on those couples wishing to havechildren... without waiting for the conclusion of this difficult and endless discussion over what should or could bethe balance between population, territory, and development" (Golini, 1994:69).

Further measures should acknowledge the fact that "a social order penalizing families with the incompatibility between school and working hours, scheduling of vacations, obstades to mobility, ini quitous taxation, and low-quality services" (Golini, 1994:17) constitutes an impediment to recovering birth rates. Based on these ideas, Livi-Bacci (1994:16) launches a proposal: the temporary levying of "another quota on income, in addition to that normally collected through taxes and contributions, so as to create a fund for reconstructing a social atmosphere conducive to higher birth rates". This would vary according to the type of job or number of children in the family and would include "all the corrective measures necessary to stop the system from becoming a sort of biological tax" (LiviBacci, 1994:16). Livi-Bacci himself defines the proposal as "problematic and provocative", and it was not very surprising that, though oriented towards a fair end, it was not pursued: partly because it reminded some people of the tax on celibacy and the awards for marriage and birth introduced in the 1920s and 30s by Fascism, but especially because current taxes are al ready too numerous and too burdensome (for those who pay them).

Far beyond the obstacles raised by prejudice and rhetoric, which trends could be established in the relationship between ethics and population policies? The idea of an 'ethical state' has been raised often and still survives in several countries, whether as various forms of dictatorship or nations where religion forms the basis of public order. Based on its intrinsic ethical principles, such a state absorbs individual demands, recognizes only one morality as valid, and dictates norms for how citizens should behave. This idea has spanned the years, almost al ways including suggestions for and/ or applications to demography: Plato's eugenic ideas, indicating that it was in the state's interest to unite the best men and women, thus perfecting the elites; demographic policies applied by Fascism and Nazism; and finally, the recent introduction, first in India, then in China, of a birth control system including rewards, sanctions, and coercive measures.

To a certain extent this idea of the ethical state pervades even the experiences of democratic states (Italy included) in the area of procreation. For example, the Rocco Code even provided prison sentences for "whoever publicly incited practices against procreation or advertised in their favor" (Article 553 of the Rocco Criminal code, 193, see above). This norm long outlived Fascism, until it was finally repealed by the Constitutional Court. Much criticism was raised recently by the negative (and at times threatening) response of religious and political celebrities to sex education in schools and public health campaigns encouraging youngsters to use condoms to prevent AIDS.

Another example was the first legislation submitted to Parliament on artificial insemination, in 1958 and 1959, as soon the first techniques appeared. These bills were peremptory in classifying such techniques as crimes, establishing jail sentences (of up to three years!) for "a married woman who agrees to heterologous artificial insemination, even with the husband's consent"; "an unmarried woman who agrees to be artificially inseminated" (in this case, with any semen); "couples requesting and agreeing to homologous artificial insemination" (husband included); "physi cians who areaccessories to the crime"; and finally, "anybody who practices insemination in a woman, even with her 
consent" (DeVincentiis \& Lauricella, 1968:14). Two underlying ethical issues can be identified in this trend. One is the fact that only that which is natural is considered good, whereas anything artificial, instead of being seen as part of the very essence of human nature, represents something evil and sinful and as such, should be incriminated. The other is the fact that accepting a donor's semen, even with the husband's consent (obviously because he has a reproductive disorder), is classified as adultery, and as such merits punishment. The bill proposed in 1959 added that "the husband can refuse to accept a child conceived in marriage through heterologous insemination" (De Vincentiis \& Lauricella, 1968:15). Recent similar decisions have been upheld by the courts, even in cases where the husband had initially agreed to the procedure.

When the notion of an ethical state is replaced by that of a state based on individual freedom, the need for rules based on moral principles is not eliminated. Quite the contrary. With regard to procreation and birth, life and old age, disease and cure, geographic stability and migration, and finally death, i.e., all the individual events that together make up a population, normative organization becomes even more complex (albeit richer in personal opportunities to be recognized and safeguarded) as compared to the mere translation of religious principles and ideologies into laws.

Human rights, pluralism, common goals

Even when rules are not written into codes (because it is not necessary and could actually be dangerous to have a law interfering with personal choices), both individuals and institutions make their decisions based not only on material interests, but also on more or less explicit moral values. Three fundamental principles serve as the basis for rules and decisions in the secular, democratic state. Religions or ideologies have been replaced by human rights, the pluralism of ideas and attitudes, and the pursuit of common goals, including equity.

Concerning human rights, and beyond the solemn and universally valid declarations of principles, we could refer to Title I (Rights and Obligations of Citizens) and Title II (Ethical and Social Relations) of the Italian Constitution (Constituzione della Repubblica Italiana, adopted in Rome, December 27, 1947). In contrast with the chapters dealing with the Order of the Republic, which are still valid and therefore not subject to revision, these are two of the most frequently examined titles. A few examples on demography and health illustrate the extent of changes and their significant moral and legal implications.

The statement of principles begins with three articles $(13,14$, and 15) proclaiming the defense of personal freedom, the inviolability of one's household, and freedom of residence, and confidentiality of mail and all other forms of communication. The only exception refers to acts originated by judicial authorities and undertaken in accordance with the law. Still, what has changed in this field of information and communication since 1948, when the Constitution was passed?

A new right was consolidated by facts and rules: that of all citizens to decide their fate, even when ill, based on practical knowledge of the ethical concept of personal autonomy. The expression 'informed consent', now accepted even by the Code of Medical Deontology, revised in 1995 (Codice di Deontologia Medica, approved by the National Medical Council, June 24-25, 1995), makes a break with the paternalistic idea of only granting information and choice of treatment to physicians. In addition to the elementary right to be treated, it also includes the right to request and obtain interruption of treatment. It is the right to oppose any therapy or its intensity: the right to die. Another right was firmly established in the collective area: that of workers and members of a territorial community to be informed as to potential sources of hazard. In recent years this has been the main driving force in research on preventive measures in environmental epidemiology and early death.

On the other hand, data collection and transmission has increased exponentially to include even the most intimate information on personal lives. This was not simply a consequence of easier methods for data gathering and processing. It has been the result of a series of coinciding factors: advances in biomedical sciences (e.g., studies on genetic identity); market and politics promoting the knowledge and use of citizens' opinions (expressed by various surveys); growth of demographic and social investigations; and especially electronic files with private and public databases, open or hidden, where each one of us, more or less knowingly, is recorded in a dozen different ways. The positive effect of all this could be a better knowledge of individuals and populations. However, it also bears the risk of breaching a right that goes far beyond that of the 'inviolability of the household' or 'confidentiality of correspondence', both proclaimed by the 
Constitution and protected under the Criminal Code: the right of citizens to privacy. This could have a negative influence on other rights. One of the most controversial cases is that of genetic screening, used either in job discrimination or to limit the extent of medical services covered by private insurance plans. European law, contrary to US legislation, is being oriented in such a way as to constrain genetic analysis in the field of labor or insurance whenever it can be used against individuals (Rodotà, 1995).

With statistical surveys, even experts in demography have faced morally and legally complex circumstances: e.g., during a census, when there is a conflict between the need to obtain information and moral doubts on the legality of some of the questions asked. What is strange is that the outcry has been far greater over some questions considered indiscreet than over the absence of questions that are hardly embarrassing, but which are necessary to paint a complete picture of the population's characteristics. For example, data on social class have been requested and used by the British Registrar General for over a century, whereas in Italy they only recently became part of the basis for a better understanding of the country's social and demographic structure. Obviously, a venial sin of action is more serious than a serious sin of omission.

Another increasingly controversial issue is described in article 29 of the Italian Constitution, according to which "the Republic recognizes the rights of the family as a natural society based on marriage". Although couples based on other criteria have existed for a long time, there is no doubt that the latter phenomenon is more frequent today. Two conditions are also new. First, such couples, considered anomalous under article 29, are considered normal by common awareness. Second, some of them have requested (and in certain cases obtained) some type of formal recognition. Statistics are now also taking this new situation into account. A question often asked is: to what extent can the Italian law defend and legitimize cases that differ from 'normalcy', like homosexual couples or polygamous families with other religious and legal traditions?

In the area of health, the Constitution's main statement (article 32: "the Republic safeguards health as a fundamental right of the individual and as a collective concern" has not only guided but anticipated history. Based on this principle, and following the most advanced ideas in medicine, a new movement emerged in the 1960s and 70s. Focused on disease prevention, it made medical services available to all citizens. Recently this article was again used to cap- ture the ethical stimulus and legal justification necessary to ensure access to health services for immigrants (even the illegal ones), as individuals, though not citizens (this is the only article in the Constitution where the word individual is used!) and because it is in society's interest to treat them, to prevent the spread of disease.

Nevertheless, for some years now, opposing forces have been attempting to produce more selective access to medical services. The most visible phenomenon in Italy is the growing inefficiency and relentless degradation of human relations in medical services, resulting in discrimination between those who have knowledge, power, and importance and those who have neither the means nor the ability to obtain treatment with the quality needed. The most significant event for ethics has been the international trend proposing rationing of treatment as a solution to the scarcity of funds for medical services (Berlinguer, 1994). Among the several criteria suggested, the prevailing one is the assessment of the 'quality of life' achievable through medical interference. This parameter must be defined 'from outside', since all individuals assign the highest value to their own lives. Besides, it contradicts the ethical principle of the intrinsic value of all human life and risks penalizing the weakest in terms of social class, age, and/or health status.

However, it is important to add that this rationing is already being adopted frequently through seldom expressed empirical (and at times brutal) methods. The transparent definition of health care priorities (I prefer this expression because rationing evokes times of war, thus leading to the notion that the right to medical care is always at war against the state's budget), may therefore be useful in achieving two goals. First, to help establish treatment guidelines before individuals are selected. Here, I am referring not only to the requirement that all treatment must be evidence-based (i.e., supported by documentation proving its effectiveness), but also to the importance of transferring resources from hospitals to territorial and home care. Second, it helps prioritize disease prevention and increases social efforts in extra-medical activities that promote health much more effectively than medicine itself.

The second fundamental principle is pluralism. Its presence in the field of ideas and attitudes regarding demographic issues is a fact. Of course this does not mean that every personal choice calls for a moral judgment. However, we must consider that organizing everything ad unum, besides being unfair (pluralism is an individual right and a resource for all) would also 
require coercive measures that would be inconsistent with a democratic society today. In areas most sensitive to rapid changes, because of technological advances or other developments that shake traditional behaviors, two things should be pursued: the creation of a 'common sense', widely and freely agreed upon, that respects personal choices and, at the same time, a system of rules capable of resolving, with minimum prohibitions, the inevitable value conflicts, bringing positive goals to the surface. This is not easy, particularly in Italy, where controversies are often dealt with on irreconcilable grounds. Nevertheless, it appears to be the only possible path.

As an example, I shall now make reference to life's two extremes: birth and death. Reproduction is certainly the area where the greatest upheavals have occurred, mainly because of the possibility of birth control along with the promotion of women's rights, i.e., legalization of abortion and the advent of medically assisted procreation (Chiavacci \& Livi-Bacci, 1995). Amongst all such advances, two have stood out more clearly. One can be defined as microethics (because it concerns individuals directly, and not because it is of minor importance). It refers to the presence (real, though almost always legally undefined) of the unborn child, who could be considered a moral subject from the very beginning.

This issue was first raised in the context of discussions regarding abortion. Act 194 of 1978 (article 1) establishes that "the state recognizes the social value of maternity and protects human life since its beginning" (Act no 194, approved May 18, 1978 by the Italian Parliament, Norme per la tutela sociale della maternità e sull'interruzi one vol ontaria della gravidanza, commonly defined as "Abortion Law"). The first part of the sentence could be read as a typical example of legislative rhetoric, a substitute for real action. The second belongs to the rank of equivocal statements, in this case willingly, but perhaps also inevitably equivocal. In fact, it is difficult for science or philosophy to univocally explain the moment at which life begins. The only certainty is that the union of the two gametes, male and female, forms a unique and genetically unrepeatable zygote. However, even this entails complexities: the initial zygote can originate two or more embryos, zygotes can unite with other zygotes up to a certain level of development...and so on. Not even the current doctrine of the Catholic Church states that every embryo is a person from the moment of fecundation onwards. Rather, it says that it could become one. Based on this possi- bility the Church builds its case, claiming protection for the embryo equal to that granted to the born child.

This issue was proposed for discussion again in an attempt to define a 'statute for the embryo'. Debates were intense in two areas: the fate of 'supernumerary embryos', a dreadful expression used to define those fertilized in vitro and not meant for implantation, and the legitimacy of experimenting with human embryos. Finally, the fate of the unborn child became the most controversial issue in discussions on regulation of assisted procreation. In 1994, when it still included all cultural tendencies, the National Committee on Bioethics made its first statement, revealing a clear preference for the unborn child's right to be born from a stable, heterosexual couple, a fact considered by some as essential and by others as useful for better formation of personal identity. Later, the Committee itself insisted on the preliminary definition of the embryo as a person, stopping the preparation of control standards in centers for medically assisted procreation. Unfortunately, today Italy is characterized by the absence of any rule, even the most basic norms for proper technical and scientific conduct, health assurance, and protection from speculation in centers using this practice. That is why our country is defined as 'the Far West of medically assisted reproduction'.

The next complex issue regarding birth pertains to the field of macroethics. It thus concerns populations in general and the ethics of public choices. The question to be asked is to what extent, using which methods, and for what reasons the state should interfere so as to establish a balance (real or presumed) between resources, territory, and population. The answer calls for an evaluation of demographic trends and projections as well as their relationship to resources and the environment. In addition, it requires a careful historical analysis of theses proposed since the 18th century, beginning with the differing opinions of Adam Smith and Thomas Robert Malthus (Rothschild, 1995) and then embarking on a reflection over the last decades, when birth control advocates appeared to oppose those who believed high birth rates were inherent to underdevelopment and demographic equilibrium inherent to development. Finally, it implies a geographical focus on situations varying widely according to the respective location and country. Besides, it would be necessary to relate all this to existing moral and religious controversies (De Sandre, 1994).

I could indicate an alternative method for those cases in which one of these analyses is 
not feasible. Political choices have often been made on the basis of mandatory contraception, and not on free choice, conviction, or convenience. The most striking of these experiences was that of India where a sterilization campaign was conducted in 1975-77, driven by financial incentives, prizes, and numerous forms of pressure. This led to a violent rebellion and was one of the causes of Indira Gandhi's downfall, since her government had promoted those measures. The population favored voluntary forms of birth control, which have accompanied the cultural and economic development of many countries all over the world. Experience proved that regulation of fertility occurs more rapidly and consistently when the rights and contribution of women in social life are recognized, and especially when girls receive the necessary education. We can therefore state that the ethical principle of responsibility used by Jonas (1990) in other areas also has practical applications.

When the problem is a low rather than high birth rate, perhaps the most effective solution (albeit difficult to apply) is that proposed by Livi-Bacci, of "increasing the confidence in life projects" (Livi-Bacci, 1994:17). Being born into this world is now strongly influenced (amongst other things) by the preliminary question often asked by parents: 'into what world?' We should worry less about embryos and 'artificial' births and more about the naturally-born who, from the beginning of their independent lives, have to deal with problems caused by others who preceded them (the 40 million to be paid on the public debt and an even heavier environmental liability), in addition to the difficulties they face as they grow and try to progress in life. If we did so, there would be more trust in the future, and birth rates might even increase. Nonetheless, I see that bioethics is as uncommitted to this goal as politics, focusing too much on controversies in the relationship between science and life and too little on daily issues.

A similar distortion is found at the other extreme of life, where bioethics favors the topic of euthanasia over that of 'normal' death. Whoever reads the literature on bioethics or checks the space in the media devoted to debates on this matter might think the world is full of people whose only wish is to perform (or have someone else perform) their own deaths. In spite of being an irrelevant phenomenon for demography, euthanasia is undoubtedly of crucial ethical importance, and it would be so even if it concerned only one person, because it deals literally with life-and-death issues. In terms of personal autonomy, I have already mentioned that one of the decisions about one's own fate is that of choosing whether or not to continue being treated. This wish can be expressed as a 'will to live', already adopted in several countries, where individuals define the decisions that have to be made (possibly naming a 'trustee') in case they can no longer express themselves. This solution is widely accepted and could thus become part of a code. However, there is much resistance (and rightly so, I must say) to the idea of allowing the administration of substances with the sole purpose of provoking death.

Nevertheless, in the vast majority of cases, what the 'terminally ill' request is not active or passive euthanasia. Rather, they ask to be aided, to receive comfort and company, to have their pain soothed, to not be subject to useless and cruel therapies. In short, they ask to die with the least pain and the greatest dignity, as late as possible. I should also add that, particularly in the demographic, social, and moral fields, the most relevant phenomenon is the infinite existence and persistence (despite medical advances) of events that could be defined as cacothanasia: the bad deaths, not only because of they way in which they occur, but also because they are premature and early deaths that could have been avoided or delayed with adequate prevention or more effective and timely treatment.

\section{Equity and the poor}

Cacothanasia is unequally distributed among individuals and peoples. Since the turn of the century, when Jacques Bertillon (1900) documented I'inégal ité sociale devant la mort as a phenomenon taking place in Paris, Berlin, and Vienna, numerous studies (that have increased over the last decade, I do not know whether due to greater differences, increased attention from experts, or the cumulative effect of both factors) have confirmed that this inequality exists everywhere, to a greater or lesser degree, depending on the time and the country (Costa \& Faggiano, 1994). Inequality persists despite medical progress and the scope of health care services, due to a variety of interrelated factors: income, education, nutrition, housing, 'life styles', environmental risks, and stress in the workplace, among others. Even without providing statistical data, which by the way can be easily obtained, I shall dwell on this phenomenon linked to inequalities in health, first because I am more experienced on the subject, but also because of its severity in the overall picture of problems related to material life. 
While in some areas (like income) it is at least theoretically feasible to pursue equality, and while in others (like justice) it has been almost universally sanctioned by law, the achievement of equality in health and quality and duration of life is not a practical or desirable objective. To expect it would mean to standardize the human kind, canceling the intrinsic value of differences among individuals

That is why it is correct to use the term 'inequality' for descriptive purposes, in statistics, while 'equity' and 'inequity' are more commonly employed for ethical dimensions and political choices. They refer to differences that are avoidable (not necessary) and considered unfair in the overall context of etiologic knowledge and social relations (Whitehead, 1990). These terms make it possible to analyze factors or groups of factors that comprise differences. In an initial assessment, we might exclude from negative ethical judgment all natural, biological variations as well as unhealthy behaviors adopted by free will (e.g., dangerous sports and risky leisure activities). On the other hand, in evaluating inequity, one must include unheal thy behaviors that provide limited choice, exposure to harmful, unhealthy, or stressful living and working conditions, and inadequate access to health care and other public services (especially education and social assistance). In some cases it is precisely poor health brought about by biological factors which causes downward social mobility and increased risk of premature or early death. Finally, there are cases in which certain disabilities (even those existing since birth) can be corrected thanks to technical and scientific advances. However, this correction is not undertaken because society has not made the necessary resources available. In such conditions, inequity emerges at later stages, even though it is not the root cause of the problem.

In other words, equity in health means that everyone should have a fair opportunity of achieving their own potential in life, and more pragmatically that nobody should be at a disadvantage whenever this can be avoided (WHO, 1986). Several obstacles must be overcome, and they vary in time and space. I wish to highlight two examples, due to their demographic interest and importance in many developed countries of Europe: unemployment and urban exclusion. Any choice made with the purpose of promoting equity in health (Dahlgren $\&$ Whitehead, 1992) must follow three criteria, described by Sonnino (1979) for all demographic policies: universality, operation of social structures, and the active role of citizens. This means not only improving specific services that partly influence health, but most importantly, other factors that affect it, such as education, work, the environment, overall levels of equity, and social solidarity.

This leads us to three very brief (and far too summarized) reflections on democracy. First, it is clear that "population policies requiretheapplication of moral principles based on sound, factual information" (Warwick, 1995:1954). However, political experience (especially in Italy) shows that even when this information is available it is frequently disregarded. In addition, in recent years, financial and institutional matters have become so overwhelming as to overshadow vital problems (here vital is to be taken literally) and social changes that should be at the core of many decisions. Occasionally some vital problems are seen only as financial variables and not for their intrinsic value. Thus, health is dealt with as an expense and the elderly simply as pensioners. A change in the political culture (and in the underlying value system) is clearly needed, so that population policies (policies with rather than for the population) will not be left as a mere addendum to fundamental decisions about the future; rather, such decisions will follow and to a certain extent precede them.

Secondly, we must consider that this trend corresponds to a severe power imbalance in the international scenario. Power has gradually shifted from the United Nations (UN) and its agencies (where at least initially the entire world population was represented) to a group of governments (known by the acronym G7) and to international monetary institutions. One of the most significant examples is the weakening of the World Health Organization in favor of the World Bank, such that the latter now defines health policies, particularly in the less developed countries. It seems only fair to say that the UN and its agencies should play a stronger role in the decision-making process, in addition to acting as the organizer of international conferences to show the way (e.g, the conferences on the environment in Rio de Janeiro, population in Cairo, women in Peking, and food policy in Rome).

The third issue regards an intrinsic limit to representative democracy. Certainly, more than any other system, representative democracy allows for the establishment of human rights, pluralism, and the pursuit of equity. However, its object is the population as a group of current, adult, voting, and participant individuals. Its rules do not (and probably could not) include a significant share of the population (in many countries the majority): i.e., the youth. 
This occurs despite some attempts (fair or simply bizarre) that include lowering the age limit for voters or granting more votes to people with children. Neither can it represent the interests of an even greater number of people: our descendants, who could be affected by our decisions (and in some cases already have been). I do not believe that legal provisions can solve this problem, except perhaps the creation of norms requiring prior evaluation and public discussion of the future impact of current projects and actions in such areas as the environment (regulations in this respect have already been passed in some countries, though limited to local impacts), health, and population. Obviously, this effort on behalf of future generations should be entrusted to moral evolution. Jonas is right in saying that traditional ethics has always been the ethics of proximity, involving human actions and limited in scope. But now is the time for a broader sense of responsibility, which requires global, continuous perspectives and a projection into the future.

\section{Summation}

Demography is based on statistical analysis. However, its definitions are impregnated with moral values that affect public policies and personal behaviors concerning birth, death, and relations between genders, generations, and migrations. Some obvious examples include the term 'illegitimate' for children of unmarried parents, spontaneous abortion, which frequently hides other issues regarding abortion, and the distinction between endogenous and exogenous mortality, which disguises the connection between biological and environmental mortality factors.

In population policies, especially in Italy and other European countries, it is feared that ethical values at the basis of public decisions might be revealed. The decision-making process is often influenced either by prejudice, as shown in the debate on immigration, or by rhetoric, as in the issue of the family, so frequently glorified in Italy but seldom the object of action in its behalf. That is the reason for the record drop in fertility and birth rates in Italy.

Demographic ethics can be built on two opposing principles in nature. One is the idea of the 'ethical state', recognizing only one morality and dictating (through its norms) how citizens should behave. This idea has traversed history and expressed itself clearly in the dictatorships of our times, prescribing or prohibiting rules on procreation, for example.
The second principle is that of a state based on individual freedom. This idea does not exclude (but certainly renders more complex) the formulation of rules on procreation, birth, life, aging, disease, cure, marriage, migration, and death. In addition, many of these events are conditioned by powerful progress in technical and biomedical sciences.

Regulations and decisions do not have to be supported by religion and ideologies. Rather, they can be based on three fundamental ethical principles, freely chosen: human rights, pluralism, and equity.

In the area of rights, however, it is no longer enough to refer to the Constitution and international agreements. This is due to the many changes produced in society. For example, more and more information on personal lives, including the genetic make-up of individuals, is being collected and transmitted. Also, the number of families not 'founded on marriage' has increased. In addition, the idea of the right to health is being replaced by that of rationed treatments and the choice of who should and who should not be treated. All this requires a revision of laws and moral rules of behavior.

Pluralism implies not only respect for personal choice, but also the quest for a generally and freely agreed-upon common sense. There might be decisions which, although subject to different moral analysis (e.g., abortion), are still respected in their autonomy. There are also collective decisions (e.g., procreation policies) that, despite their common goals, fully respect individual freedom. Finally, there are 'borderline areas', like termination of life. In this case, though continuing the discussion on euthanasia, it would be important to worry more about everyone's primary right to die with the least pain and the greatest dignity, as late as possible.

This is closely linked to the third principle, equity, mentioned by several demographers in their research on inequality in the context of disease and death. They refer to conditions which are avoidable and therefore unfair, because scientific progress allows for the prediction and prevention of many diseases and various causes of premature death.

The three principles listed above require a few comments on democracy. First of all, democracy must be based on accurate information on population trends, and not only on economic and financial data. It must also be universal, to oppose the ongoing centralization of powers. Finally, it must address future as well as present populations. As a result, it is necessary to move from the ethics of proximity to ethics based on greater human responsibility in space and time. 


\section{References}

BERLINGUER, G., 1994. Etica della Salute. Milano: II Saggiatore.

BERLINGUER, G.,1996. I flussi migratori in Italia: aspetti giuridici ed etici. Presented at 37o Congresso Nazionaledi Igiene, Napoli.

BERTILLON, J., 1900. Mouvements de population et causes de décès selon le degré d'aisance à Paris, Berlin. Vienne. Presented at X Congresso Internazionale di Igiene e Demografia, Paris, Annals, pp. 961.

CAVALLI-SFORZA, L., 1996. Geni, Popoli eLingue. Milano: Adelphi.

CHIAVACCI, E. \& LIVI-BACCI, M., 1995. Etica e Riproduzione. Un Teologo e un Demografo a Confronto. Firenze: Le lettere.

COSTA, G. \& FAGGIANO, F., 1994. L'equità Nella Salute in Italia. Milano: Franco Angeli.

DAHLGREN, G. \&WHITEHEAD, M., 1992. Policies and Strategies to Promote Equity in Health. Copenhagen: WHO.

De SANDRE, P., 1994. Demografia, politica ed etica. In: Demografia (M. Livi-Bacci, G. C. Blangiardo \& A. Golini, org.), pp. 541-482, Torino: Fondazione Agnelli.

De VINCENTIIS, G. \& LAURICELLA, E., 1968. Necessità di una urgente revisione della legislazione $e$ dei regolamenti in campo ostetrico-ginecologico. Presented at LIII Congresso della Soci età Italiana di Ostetricia e Ginecologia, Rome.

FAGOT-LARGEAULT, A., 1989. Les Causes de la Mort. Histoire Naturelle et Facteurs de Risque. Paris/ Lyon: Librairie Philosophique J.Vrin/Institut Interdisciplinaire d'Études Épistemologiques.

FARR, W., 1885. Vital Statistics: a Memorial Volume. Londres: Noel Humphreys/Sanitary Institute of Great Britain.
GOLINI, A., 1989. Una Politica per L'Immigrazione Straniera in Italia. Working paper 03/89. Roma: Consiglio Nazionale delle Ricerche/Istituto di Studi sulla Popolazione,.

GOLINI, A., 1994. Tendenze Demografichee Politiche per la Popolazione. Terzo Rapporto IRP. Bologna: II Mulino.

JONAS, H., 1990. II Principio Responsabilità. Un'etica per la Civiltà Tecnologica. Torino: Einaudi Editore.

LIVI-BACCI, M., 1994. Introduction. In: Tendenze Demografiche e Politiche per la Popolazione. Terzo Rapporto IRP (A. Golini, org.), pp. 1-18, Bologna: II Mulino.

REICH, W. T., 1995. Encyclopedia of Bioethics. Revised edition. New York: Simon \& Schuster Mac Millan.

RODOTÀ, S., 1995. Tecnologie e Diritti. Bologna: II Mulino.

ROTHSCHILD, E., 1995. Social security and laissez faire in the eighteenth-century political economy. Population and Development Review, 21:711-744.

SONNINO, E., 1979. Aspetti eProblemi di Demografia Sociale e di Politica della Popolazione in Italia. Roma: Istituto di Demografia dell'Università di Roma.

TALAM ANCA, I. F., 1994. I Tossici Ambientali e Lavorativi ela RiproduzioneUmana. Padova: Piccin.

WARWICK, D. W., 1995. Elements of population ethics. In: Encyclopedia of Bioethics, (W. T. Reich, ed.), pp. 1.954, New York: Simon \& Schuster Mac MilIan.

WHITEHEAD, M., 1990. The Concepts and Principles of Equity and Health. Copenhagen: WHO.

WHO (World Health Organization), 1986. Social Justice and Equity in Health, a Report of a WHO Meeting. Copenhagen: WHO.

WHO(World Health Organization), 1995. The State of theWorld Health. Geneva: WHO. 